Review

\title{
Transition metal (Mo, Fe, Co, and Ni)-based catalysts for electrochemical $\mathrm{CO}_{2}$ reduction
}

\author{
Jinhui Hao, Weidong Shi * \\ School of Chemistry and Chemical Engineering, Jiangsu University, Zhenjiang 212013, Jiangsu, China
}

\section{A R T I C L E I N F}

\section{Article history:}

Received 22 February 2018

Accepted 7 April 2018

Published 5 July 2018

\section{Keywords:}

Transition metal

Energy conversion

Electrocatalytic

$\mathrm{CO}_{2}$

\begin{abstract}
A B S T R A C T
The electrochemical conversion of $\mathrm{CO}_{2}$ into value-added chemicals and fuels has attracted widespread concern since it realizes the recycling of greenhouse gases. Production of new materials lies at the very core of this technology as it enables the improvement of developmental efficiency and selectivity by chemical optimization of morphology and electronic structure. Transition metal-based catalysts are particularly appealing as their $d$ bands have valence electrons which are close to the Fermi level and hence overcome the intrinsic activation barriers and reaction kinetics. The study of $\mathrm{Mo}, \mathrm{Fe}, \mathrm{Co}$, and Ni-based materials in particular is a very recent research subject that offers various possibilities in electrochemical $\mathrm{CO}_{2}$ reduction applications. Herein, we summarize the recent research progress of Mo, $\mathrm{Fe}, \mathrm{Co}$, and Ni-based catalysts and their catalytic behavior in electrochemical $\mathrm{CO}_{2}$ reduction. We particularly focus on the relationship between structures and properties, with examples of the key features accounting for the high efficiency and selectivity of the $\mathrm{CO}_{2}$ reduction process. The most significant experimental and theoretical improvements are highlighted. Finally, we concisely discuss the scientific challenges and opportunities for transition metal-based catalysts.

(C) 2018, Dalian Institute of Chemical Physics, Chinese Academy of Sciences. Published by Elsevier B.V. All rights reserved.
\end{abstract}

\section{Introduction}

The unchecked global $\mathrm{CO}_{2}$ emissions arising from wide-spread utilization of fossil fuels have caused serious environmental problems. The development of a renewable energy device with a high energy density and reversible reaction for power generation is still an ongoing challenge. Among numerous efforts, the conversion of $\mathrm{CO}_{2}$ into value-added chemicals and fuels has been a widespread concern since it realizes the recycling of greenhouse gases [1]. Compared with the currently developed conversion methods (photochemical, biochemical and thermochemical), electrochemical $\mathrm{CO}_{2}$ reduction is one of the most ideal conversion technologies as the required electricity could be derived from renewable energy sources [2]. Elec- trochemical $\mathrm{CO}_{2}$ reduction also possess some intrinsic advantages, such as a stable catalytic efficiency, controllable selectivity, simple reaction unit and potential for industrial application [2].

The electrolyze for electrochemical $\mathrm{CO}_{2}$ reduction has four components (Fig. 1): an electrolyte that has high conductivity and allows fast mass transport of the reactants and products, a proton membrane to mitigate the oxidation of liquid products, a cathode, and an anode that is coated with highly active and durable catalysts. When an external voltage is applied to the electrodes, the electrochemical $\mathrm{CO}_{2}$ reduction takes place at the catalyst-electrolyte interface of cathode. Typically, the catalytic process involves four major steps (Fig. 1): (1) chemical adsorption of $\mathrm{CO}_{2}$ on the catalyst surface; (2) chemical activation of

\footnotetext{
* Corresponding author. E-mail: swd1978@ujs.edu.cn

This work was supported by the National Natural Science Foundation of China (21477050, 21522603, 21706101), the Henry Fok Education Foundation (141068), Six Talents Peak Project in Jiangsu Province (XCL-025), and the Chinese-German Cooperation Research Project (GZ1091), the China Postdoctoral Foundation (2017M611731).
}

DOI: 10.1016/S1872-2067(18)63073-6| http://www.sciencedirect.com/science/journal/18722067 | Chin. J. Catal., Vol. 39, No. 7, July 2018 


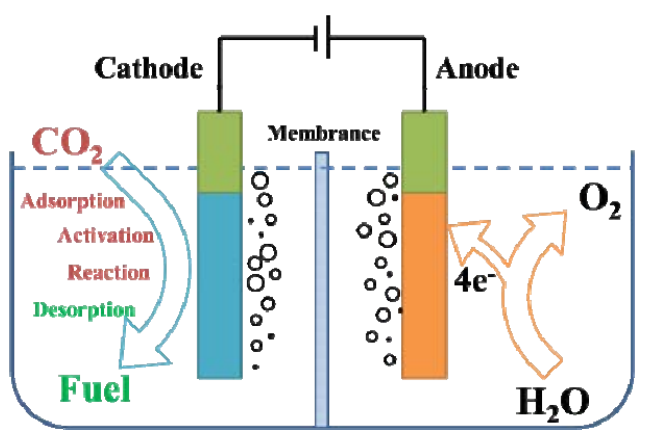

Fig. 1. Illustration of a reaction unit and the four major steps for electrochemical $\mathrm{CO}_{2}$ reduction.

$\mathrm{CO}_{2}$ to $\mathrm{CO}_{2}{ }^{--}$; (3) multiple electron/proton transfer processes induce the reduction of $\mathrm{CO}_{2}$; (4) desorption of products from catalyst surface. For step (1), the $\mathrm{CO}_{2}$ concentration in the electrolyte strongly influences adsorption rate, and a $\mathrm{CO}_{2}$ saturated electrolyte is adopted to ensure full interaction between $\mathrm{CO}_{2}$ and the catalyst. Step (2) contains one electron transfer process which forms the key intermediate $\mathrm{CO}_{2}{ }^{-}$. Due to the extremely stable property of $\mathrm{CO}_{2}$, the activation process needs a significant amount energy to rearrange the linear molecules into a bent radical anion, which is considered to be the rate determining step. Step (3) involves multiple electron/proton coupling processes whose obtained products are always complexes. For step (4), the inefficient desorption of products would reduce the active area of the electrode and block electrolyte diffusion, inhibiting further electrochemical reaction. Overall, many factors influence the efficiency and selectivity of electrochemical $\mathrm{CO}_{2}$ reduction. Therefore, the acceleration of $\mathrm{CO}_{2}$ adsorption, the promotion of electron/proton transfer, the reduction of reaction kinetic barriers, as well as the facilitation of obtained desorption products are expected to effectively improve the activity of electrochemical $\mathrm{CO}_{2}$ reduction.

The electrochemical $\mathrm{CO}_{2}$ reduction involves several proton-coupled multiple-electron transfer processes. According to different electron/proton transfer amounts, the reaction can be divided into two-, four-, six-, eight-, and twelve-electron pathways in aqueous mediums. The possible reactions for the major products are listed below (Reaction (2)-(7)) alongside the corresponding standard potentials of the reactions, $E^{0}$, with respect to the standard hydrogen electrode $\left(\mathrm{pH} 7,25{ }^{\circ} \mathrm{C}, 1\right.$ atmosphere gas pressure).

$$
\begin{array}{cr}
\mathrm{CO}_{2}+\mathrm{e}^{-} \rightarrow \mathrm{CO}_{2}{ }^{-} & E^{0}=-1.90 \mathrm{~V} \\
\mathrm{CO}_{2}+2 \mathrm{H}^{+}+2 \mathrm{e}^{-} \rightarrow \mathrm{CO}+\mathrm{H}_{2} \mathrm{O} & E^{0}=-0.52 \mathrm{~V} \\
\mathrm{CO}_{2}+2 \mathrm{H}^{+}+2 \mathrm{e}^{-} \rightarrow \mathrm{HCOOH} & E^{0}=-0.61 \mathrm{~V} \\
\mathrm{CO}_{2}+4 \mathrm{H}^{+}+4 \mathrm{e}^{-} \rightarrow \mathrm{HCHO}+\mathrm{H}_{2} \mathrm{O} & E^{0}=-0.51 \mathrm{~V} \\
\mathrm{CO}_{2}+6 \mathrm{H}^{+}+6 \mathrm{e}^{-} \rightarrow \mathrm{CH}_{3} \mathrm{OH}+\mathrm{H}_{2} \mathrm{O} & E^{0}=-0.38 \mathrm{~V} \\
\mathrm{CO}_{2}+8 \mathrm{H}^{+}+8 \mathrm{e}^{-} \rightarrow \mathrm{CH}_{4}+2 \mathrm{H}_{2} \mathrm{O} & E^{0}=-0.24 \mathrm{~V} \\
2 \mathrm{CO}_{2}+12 \mathrm{H}^{+}+12 \mathrm{e}^{-} \rightarrow \mathrm{C}_{2} \mathrm{H}_{4}+4 \mathrm{H}_{2} \mathrm{O} & E^{0}=-0.34 \mathrm{~V} \\
2 \mathrm{H}^{+}+2 \mathrm{e}^{-} \rightarrow \mathrm{H}_{2} & E^{0}=-0.42 \mathrm{~V}
\end{array}
$$

The possibility of electrochemical reduction processes is not only decided by the thermodynamic value $E^{0}$, but also relies on kinetic properties. Experimentally, a large overpotential (the difference between the equilibrium and applied potentials) is needed when catalysts are applied and the $E^{0}$ values for differ- ent products have similar value. The products obtained at fixed overpotential are commonly a mixture rather than single product. Moreover, the $E^{0}$ values between the electrochemical $\mathrm{CO}_{2}$ reduction and hydrogen evolution reactions are quite close. As the result, the hydrogen evolution reaction becomes the main competitive reaction. Overall, the reaction system is very complicated, making it quite challenging to reduce $\mathrm{CO}_{2}$ to the desirable product with high efficiency.

The development of catalysts with high efficiency and selectivity has been the research focus. In the view of reaction kinetics, current catalysts still struggle to overcome the high reaction barrier and often exhibit sluggish reaction rates during electrochemical $\mathrm{CO}_{2}$ reduction [3]. Moreover, different transformation routes could coexist in one system and the types of products would therefore be complicated, as an electrochemical reaction involves multiple electrons/protons coupling and transfer steps. Contrarily, precious metal-based materials show relatively high activity for electrochemical $\mathrm{CO}_{2}$ reduction, but their scarcity in nature limits their wide-scale deployment. Inexpensive copper-based materials have been extensively studied for electrochemical $\mathrm{CO}_{2}$ reduction due to their outstanding conductivity, unique chemical property, and excellent multiple-proton and electron-transfer abilities. Generally, copper-based materials are capable of binding and converting $\mathrm{CO}_{2}$ to higher value-added products (such as hydrocarbons and alcohols). However, the copper-based materials still suffer from poor product selectivity, activity loss due to catalyst poisoning, and limited efficiency. As a more inexpensive material, carbon-based catalysts have been utilized as catalysts for electrochemical $\mathrm{CO}_{2}$ reduction due to their high surface area, outstanding conductivity, excellent chemical stability, and remarkable mechanical strength [4-7], with CO being the majority product. However, pure carbon catalysts possess null activity for $\mathrm{CO}_{2}$ activation or intermediate adsorption. The carbon-based materials show low activity and selectivity toward electrochemical $\mathrm{CO}_{2}$ reduction. Therefore, the development of new catalysts with high efficiency and selectivity is more appealing for solving the key scientific problems in current-day technology.

\section{Advanced transition metal-based catalysts for electrochemical $\mathrm{CO}_{2}$ reduction}

Transition metals have valence electrons in $d$ bands which are close to the Fermi level (Fig. 2) [8]. With the $d$ band filled, the relative position of $d$ states center and the Fermi level shifts. As a result, transition metal-based materials show a variety of characteristics signaling a capability for use in catalytic reactions and thus offer many possibilities in a wide range of energy-related applications. Electrochemical $\mathrm{CO}_{2}$ reduction is a multi-step electron/proton coupling reaction with its intrinsic activity determined by the electronic behaviors on the catalyst surface. In this situation, the variability of the transition metal valence electronic structure makes it an ideal candidate for improving the efficiency and selectivity of electrochemical $\mathrm{CO}_{2}$ reduction. 


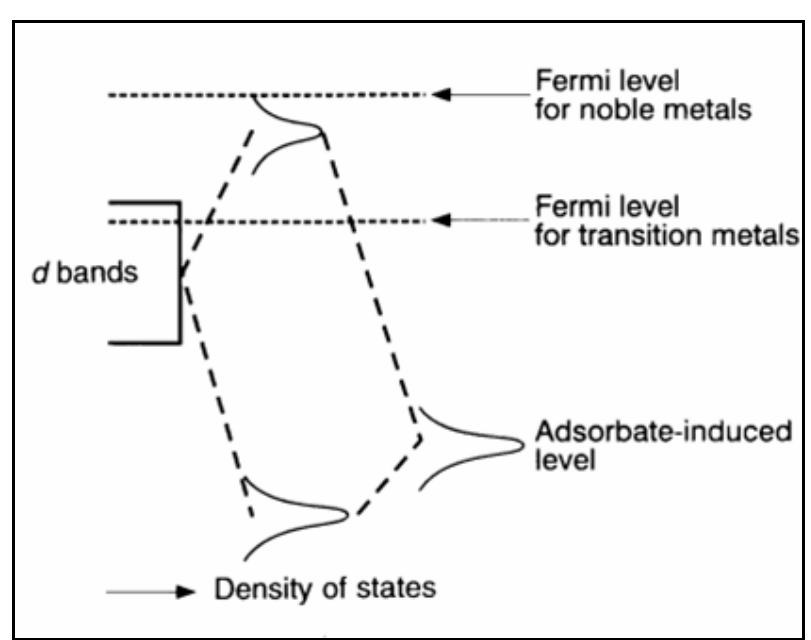

Fig. 2. The $d$ states and Fermi level for transition metals. Figure taken from Ref. [8].

\subsection{Mo-based catalysts}

$\mathrm{MoS}_{2}$ possesses unique physical properties and stacked layers similar to graphite and has been considered a promising catalyst for many applications. For $\mathrm{CO}_{2}$ reduction, the linear scaling relationships between intermediates pose a fundamental limitation to the overall efficiency of transition metal-based catalysts. The overpotential would need to maintain a high value as the relative binding strengths of the different intermediates generally correlate with each other linearly. This would imply that tuning the adsorption energy of a specific intermediate will lead to a change in the adsorption energies of the other intermediates. Nørskov et al. explored the importance of stabilizing ${ }^{*} \mathrm{COOH},{ }^{*} \mathrm{CHO}$ and ${ }^{*} \mathrm{COH}$ with respect to ${ }^{*} \mathrm{CO}$ on $\mathrm{MoS}_{2}$, $\mathrm{MoSe}_{2}$, and Ni-doped $\mathrm{MoS}_{2}$ surfaces in breaking the linear scaling relationships using density functional theory (DFT) calculations $[9,10]$. The theoretical results indicated the bridging $\mathrm{S}$ or Se atoms at the edges of the $\mathrm{MoS}_{2}$, Ni-doped $\mathrm{MoS}_{2}$, and $\mathrm{MoSe}_{2}$ surfaces could bind ${ }^{*} \mathrm{CHO}$ and ${ }^{*} \mathrm{COOH}$, but not ${ }^{*} \mathrm{CO}$. In this scenario, the adsorption energy of intermediates can be varied independently, thereby breaking the linear scaling relationships. For all the cases, the $\mathrm{S}$ or Se edges show better selectivity towards $\mathrm{CO}_{2}$ reduction over hydrogen evolution reactions than Mo edges. They predicted the possibility of deviations from the linear scaling relationships if key intermediates bind to different sites. These findings indicate the determination of a kinetic electron/proton transfer barrier and that selectivity is critical for high performance catalyst design.

In 2014, Salehi-Khojin et al. [11] reported the first $\mathrm{MoS}_{2}$ catalyst for electrochemical $\mathrm{CO}_{2}$ reduction in an ionic liquid using a two-compartment three-electrode electrochemical cell. The $\mathrm{MoS}_{2}$ catalyst showed a significantly high current response (65 $\mathrm{mA} \mathrm{cm}-2$ at an overpotential of $654 \mathrm{mV}$ ) and high selectivity
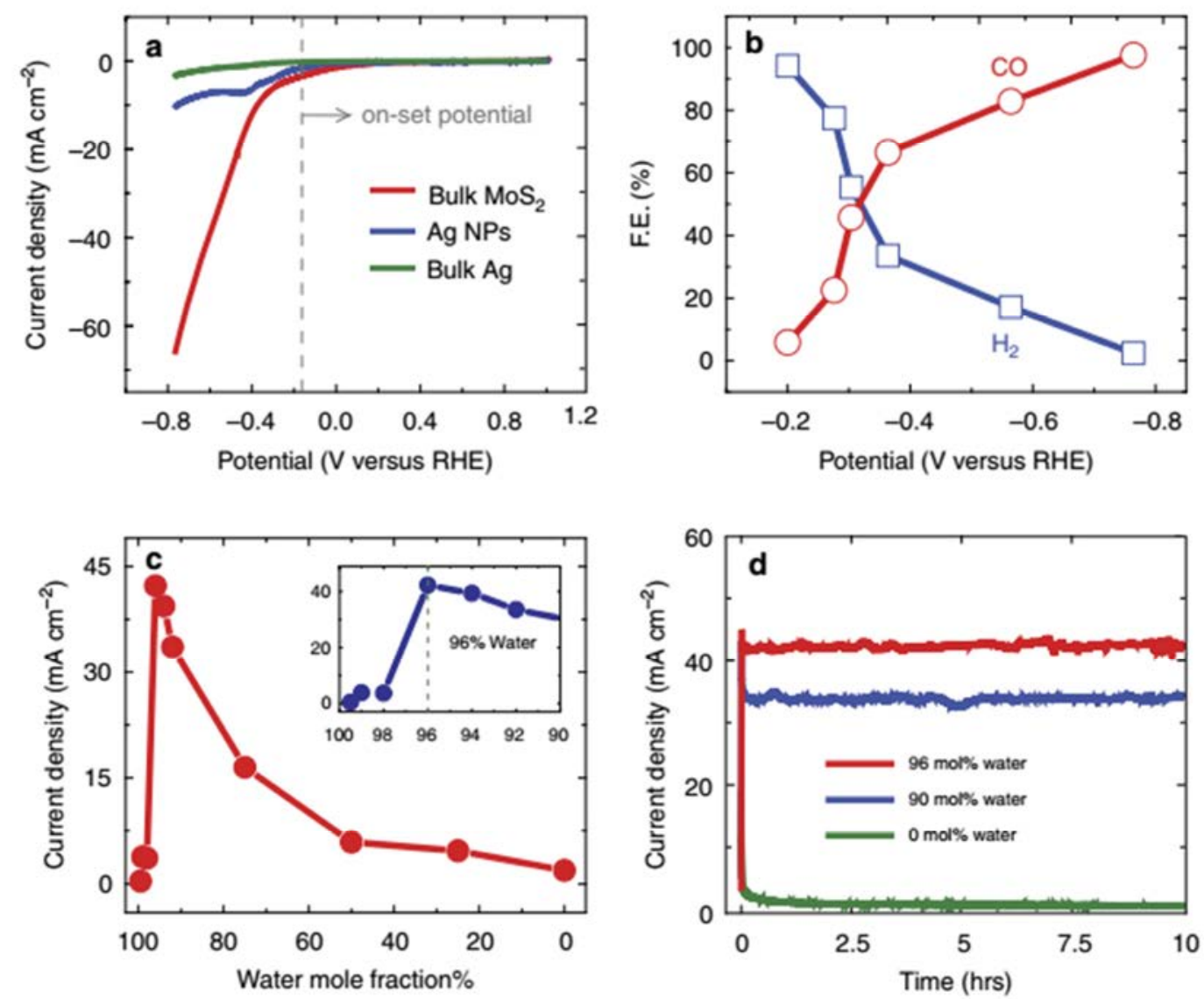

Fig. 3. Electrochemical $\mathrm{CO}_{2}$ reduction performance. (a) Cyclic voltammetric curves. (b) Faradaic efficiency at different applied potentials. (c) The current density as a function of different electrolysis. (d) Stability tests. Figure taken from Ref. [11]. 
(Faradaic efficiency of approximately 98\%) for CO formation (Fig. 3(a) and (b)). Long-term stability tests indicate the $\mathrm{MoS}_{2}$ catalysts remain stable for $10 \mathrm{~h}$ (Fig. 3(d)). Using DFT calculations, they found that the catalytic activity was primarily related to the edge states of Mo atoms. The Mo-edge atoms display metallic character and have high $d$-electron density near the Fermi level, which are suitable active sites for $\mathrm{CO}_{2}$ reduction. Ionic liquid could reduce the reaction barrier for electrons passing into $\mathrm{CO}_{2}$ by forming ionic liquid- $\mathrm{CO}_{2}$ complexes. The complexes then physically absorb at the negatively charged cathode, which result in the positioning of $\mathrm{CO}_{2}$ molecules close to the $\mathrm{MoS}_{2}$ surface and leads to a high reaction rate (Fig. 3(c)). They also employed a series of transition metal dichalcogenide as high performance electrochemical $\mathrm{CO}_{2}$ reduction catalysts [12]. The high performance could be ascribed to the active edge sites and efficient electron transfer properties. The calculated free energy diagrams suggest that the formation of $\mathrm{CO}^{*}$ from $\mathrm{CO}_{2}$ is more kinetically favorable, resulting in lower overpotentials. Further study revealed that the edge sites tended to have high CO coverage to maintain a high turnover rate during the catalytic reaction. MoP can also be employed as catalysts for high performance electrochemical $\mathrm{CO}_{2}$ reduction to $\mathrm{HCOOH}$ [13]. The MoP supporting In-doped carbon exhibited the heretofore highest Faradaic efficiency of $96.5 \%$ with a current density of $43.8 \mathrm{~mA} \mathrm{~cm}^{-2}$. The excellent performance can be ascribed to the low interfacial charge transfer resistance, strong intermediate adsorption ability, and the synergistic effect. Doping is an efficient approach to regulate the electronic behaviors on a catalysts surface. By introducing $\mathrm{Nb}$ dopant, the electronic properties show significant deviation from that of pristine $\mathrm{MoS}_{2}$ because of the different number of valence electrons for Mo and $\mathrm{Nb}$ atoms [14]. As the result, the edge Mo atoms exhibit a metallic behavior, which alters the kinetics for intermediate adsorption, enhancing the formation of CO. With $5 \% \mathrm{Nb}$ doping, the vertically aligned $\mathrm{MoS}_{2}$ exhibits a CO formation turnover frequency 1 order of magnitude higher than that of pristine $\mathrm{MoS}_{2}$. Similar to Nb, Bi dopant could also efficiently drive $\mathrm{CO}$ generation in the presence of an ionic liquid. When introducing Bi into $\mathrm{MoS}_{2}$, the obtained catalyst shows high performance for the production of $\mathrm{CH}_{3} \mathrm{OH}$ [15]. Furthermore, during electrochemical $\mathrm{CO}_{2}$ reduction process, $\mathrm{CO}$ and $\mathrm{H}_{2}$ could be produced simultaneously. $\mathrm{CO}$ is bound on the catalyst surface and then hydrogenated to $\mathrm{CH}_{3} \mathrm{OH}$. In addition, the $\mathrm{Bi}$ dopant can also stabilize $\mathrm{CO}_{2}{ }^{--}$intermediates and thus significantly reduce the overpotential. Yu et al. [16] synthesized $\mathrm{Cu}$-interspersed $\mathrm{MoS}_{2}$ and utilized it for electrochemical $\mathrm{CO}_{2}$ reduction. $\mathrm{Cu}$-interspersed $\mathrm{MoS}_{2}$ led to enhanced electronic conductivity and specific surface area, as well as improved $\mathrm{CO}_{2}$ adsorption capacity. This resulted in a significant increase in overall efficiency and selectivity.

\subsection{Fe-based catalysts}

The carbon monoxide dehydrogenase enzyme, with the $\mathrm{Ni}-\left[\mathrm{Fe}_{4} \mathrm{~S}_{4}\right]$ functional group, has been shown to efficiently and reversibly catalyze the reduction of $\mathrm{CO}_{2}$ to $\mathrm{CO}$. DFT calculations indicate the Fe sites in enzyme are the primary active sites during $\mathrm{CO}_{2}$ reduction [17]. Costentin et al. [18] found the introduction of phenolic groups could speed up catalytic process by using electrogenerated iron(0) complexes. Further substitution of the four parahydrogens by trimethylammonium groups would produce a water-soluble molecular catalyst for electrochemical $\mathrm{CO}_{2}$ reduction [19]. When molecular Fe on carbon nanotubes via noncovalent interactions are employed, the composite shows high selectivity and rapid catalytic process towards $\mathrm{CO}_{2}$ to $\mathrm{CO}$ conversion [20]. Wallace et al. [21] found that the addition of ionic liquid could increase catalytic activity of molecular Fe. The ionic liquid affects a positive shift in the potential required for the reduction of $\mathrm{Fe}^{1}$ to $\mathrm{Fe}^{0}$ rather than a proton source to facilitate the $\mathrm{CO}_{2}$ transportation. This leads to a lower overpotential and substantially higher current density [21]. The other group further reported that immobilization of a monolayer of molecular Fe via a phosphonic acid anchor could allow for $\mathrm{CO}_{2}$ to $\mathrm{CO}$ conversion with very low catalyst loading [22]. For inorganic Fe-based catalysts, DFT calculations found that the surface structure of FeS played an important role in the activation of $\mathrm{CO}_{2}$ [23]. The $\mathrm{CO}_{2}$ molecules tend to adsorb on the (011) and (111) FeS surfaces, preferentially at Fe sites. The charge transfer accrued from the Fe species to the $\mathrm{CO}_{2}$ molecules and thus facilitated the activation of $\mathrm{CO}_{2}$ molecules. On the (111) surfaces, Fe sites exhibit the best performance for $\mathrm{CO}_{2}$ reduction. Kolpak et al. [24] employed $\mathrm{Fe}$ as individual $d$ state components on WC. After introducing Fe, the adsorption energies of $\mathrm{CO}$ and $\mathrm{O}$ decreased compared to pure $\mathrm{WC}$, changing the preferred reaction pathway from oxophilic to carbophilic. The two different interfaces could then provide different active sites, which enable an alternative approach for overcoming scaling relations and thus optimize the reaction steps. This new model can explain both site preference and binding-energy trends. This approach highlights a new avenue to tailor catalysts with desirable product selectivity and optimized activation overpotential. Experimentally, Li et al. [25] found that the primary role of the Fe dopant was identified to reduce the reaction barriers, exhibiting the lowest onset overpotential of $0.19 \mathrm{~V}$ when obtaining CO.

\subsection{Co-based catalysts}

Inorganic Co-based catalysts have emerged as a promising candidate for HER applications owing to their abundant reserves, thermal stability, and low cost. Inorganic Co-based catalysts are considered nearly non-catalytic for electrochemical $\mathrm{CO}_{2}$ reduction. In 2016, Xie et al. [26] developed the first inorganic Co-based catalyst for electrochemical $\mathrm{CO}_{2}$ reduction by modifying morphology and oxidation states. They constructed an ideal model of an intact metal atomic layer and then created oxide on its surface. The hybrid 4-atom-thick layer structure ensures that most of the metal atoms serve as either surface atoms or surface ions, which allow for the two typical active sites for surface catalytic reactions (Fig. 4). The partially oxidized Co catalyst shows higher intrinsic activity and selectivity towards $\mathrm{HCOOH}$ production at lower overpotentials than pure Co. The electrochemical $\mathrm{CO}_{2}$ reduction activity gradually increases as the $\mathrm{Co}_{3} \mathrm{O}_{4}$ content increases, indicating that the 

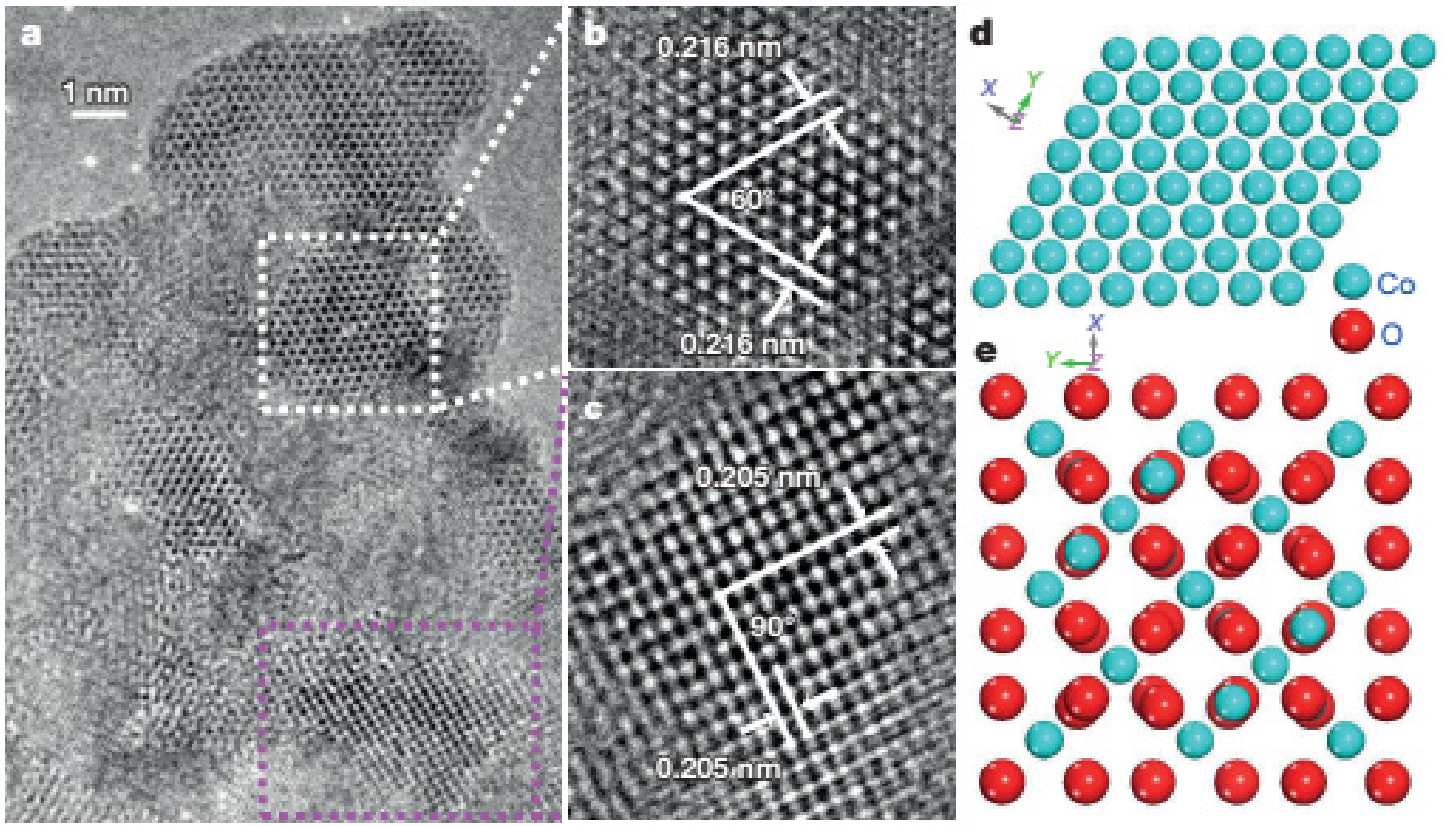

Fig. 4. Characterizations for the partially oxidized 4-atom-thick Co layers. (a-c) High-resolution TEM images. (d, e) The related schematic atomic models. Figure taken from Ref. [26].

presence of intrinsically more active site is associated with the oxidation states. Based on the $\mathrm{Co} / \mathrm{Co}_{3} \mathrm{O}_{4}$ system describe above, Xie et al. [27] further reported atomic layers for $\mathrm{Co}_{3} \mathrm{O}_{4}$ as promising catalysts for electrochemical $\mathrm{CO}_{2}$ reduction. The obtained atomic-layer catalysts possess abundant active sites and high electrical conductivity, which greatly promote the reaction kinetics. The atomic $\mathrm{Co}_{3} \mathrm{O}_{4}$ layers donate one fast electron during pre-equilibrium transfer to form the $\mathrm{CO}_{2}{ }^{--}$intermediate and thus exhibit higher intrinsic activity than bulk $\mathrm{Co}_{3} \mathrm{O}_{4}$. The thinner structure also provides the $\mathrm{Co}_{3} \mathrm{O}_{4}$ layers with many dangling bonds, which become the active site during catalytic reaction and ensure higher intrinsic catalytic activity. Using DFT calculations, they revealed that the ultrathin $\mathrm{Co}_{3} \mathrm{O}_{4}$ layers had a more dispersed charge density near the Fermi level, which enhance electronic conductivity and promote faster carrier transport which participate in the reduction reactions (Fig. 5). Along with this work, Xi et al. [28] recently reported the fabrication of vacancy-rich $\mathrm{Co}_{3} \mathrm{O}_{4}$ single-unit-cell layers, the subjection of vacancy-rich $\mathrm{Co}_{3} \mathrm{O}_{4}$ as efficient catalysts for electrochemical $\mathrm{CO}_{2}$ reduction, and the identification of intrinsic activity by exploring the composition configurations and their correlations with electrochemical performance. There is theoretical and experimental evidence that suggests that the proton transfer process is the rate-limiting step, while the presence of oxygen (II) vacancies can stabilize the intermediate compounds. As the result, the vacancy-rich $\mathrm{Co}_{3} \mathrm{O}_{4}$ single layers showed high current response and $\mathrm{HCOOH}$ selectivity. Lee et al. [29] prepared a $\mathrm{Co}_{3} \mathrm{~S}_{4}-\mathrm{Co}_{3} \mathrm{O}_{4}$ core-shell octahedron structure for electrochemical $\mathrm{CO}_{2}$ reduction applications. The synergistic interaction between the composites can reduce the reaction barriers and enable fast electron transfer, facilitating the kinetics for intermediate adsorption. Molecular Co is also proven to be efficient catalysts for electrochemical $\mathrm{CO}_{2}$ reduction. Sun et al. [30] constructed a molecular Co nanotube model and systematically studied the influence of geometric and electronic structures and stability on electrocatalytic activity. Large diameter nanotubes were found to be beneficial for $\mathrm{CO}_{2}$ to $\mathrm{CO}$ conversion, while the high curve nanotubes with smaller radii could further catalyze $\mathrm{CO}$ reduction to produce $\mathrm{CH}_{4}$. The $\mathrm{pH}$ of electrolysis also plays an important role for the formation of $\mathrm{CO}$ and methane. An appropriate $\mathrm{pH}$ would affect the protonation process from a direct adduction into an indirect pathway and thus promote the electrochemical $\mathrm{CO}_{2}$ reduction process [31] When employing molecular Co on carbon-based materials, the complexes significantly improve the catalytic activity and the products selectivity [32]. The electrochemical $\mathrm{CO}_{2}$ reduction performance could be further benefitted with molecular level structure optimization. Moreover, carbon nanotubes can also facilitate the adsorption and reaction of $\mathrm{CO}_{2}$ in a given aqueous medium [33].

\subsection{Ni-based catalysts}

In the carbon monoxide dehydrogenase enzyme, $\mathrm{Ni}$ atoms could lower the energy pathway and improve the selectivity for $\mathrm{CO}_{2}$ to $\mathrm{CO}$ conversion [17]. Ni-based materials are considered as potential catalysts for electrochemical $\mathrm{CO}_{2}$ reduction. Nanomaterials exhibit unexpected properties when they are downsized to atomic scale because of their unique electronic and geometric structures. Hashimoto et al. [34] reported the first inorganic Ni-based catalyst (Ni-N-graphene oxide) for high performance $\mathrm{CO}_{2}$ conversion and provide atomic-level insight into the influence of $\mathrm{Ni}-\mathrm{N}$ bonds. $\mathrm{N}$ and $\mathrm{Ni}$ potentially influence the selectivity of electrochemical $\mathrm{CO}_{2}$ reduction. Wu et al. [35] constructed a Ni-N $\mathrm{N}_{4}$ structure through a topochemical transformation strategy. The outer carbon layer can ensure the 

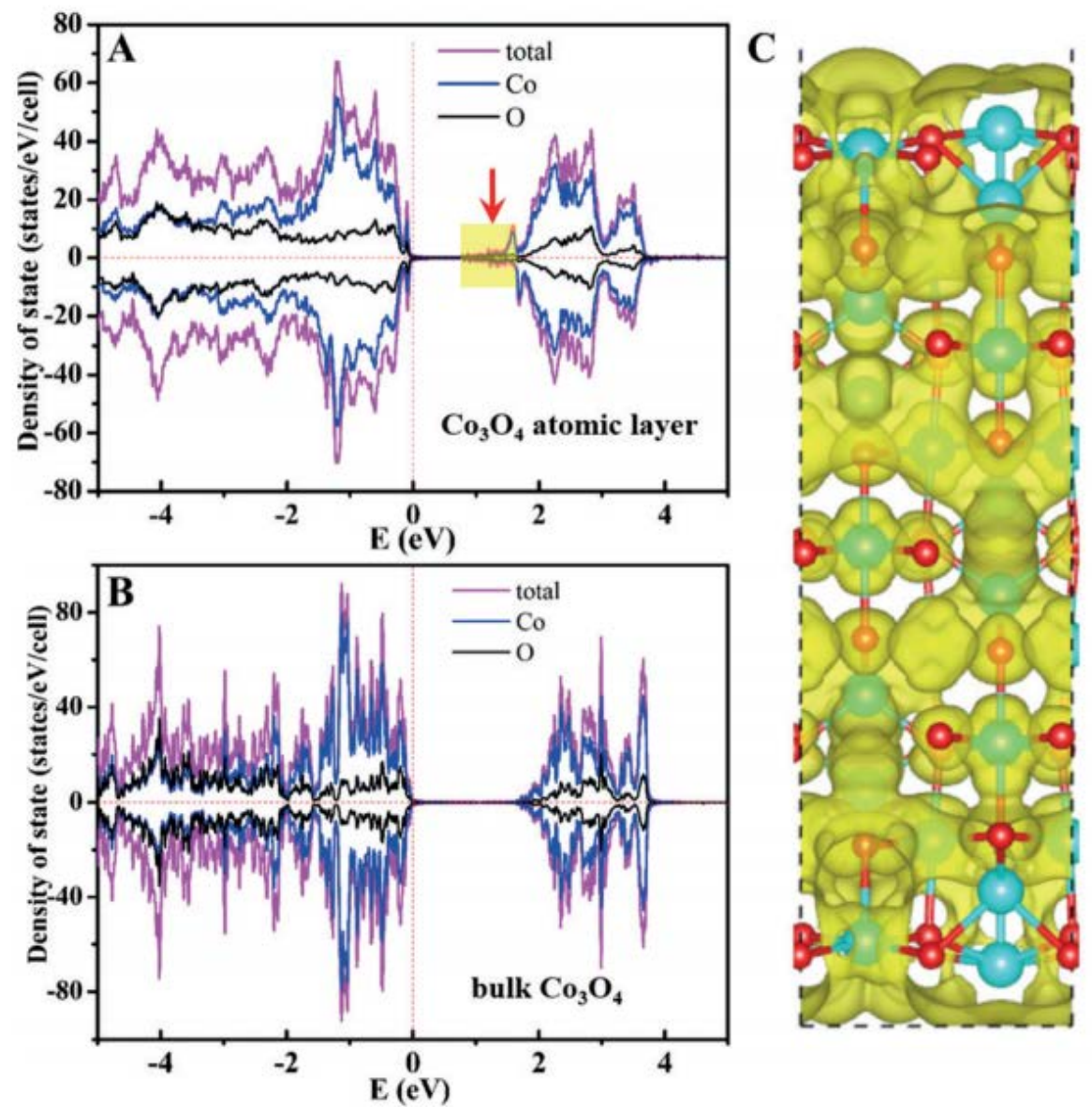

D
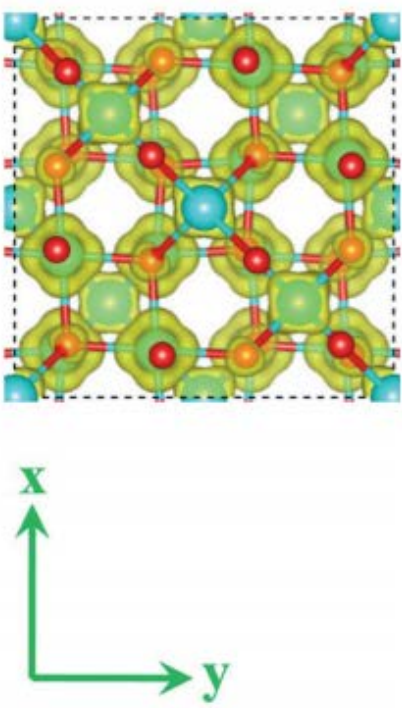

Fig. 5. Density of state for the $\mathrm{Co}_{3} \mathrm{O}_{4}$ atomic layer slab with thickness of $1.72 \mathrm{~nm}(\mathrm{~A})$ and bulk $\mathrm{Co}_{3} \mathrm{O}_{4}$ slab (B); (C) The partial charge density distribution of the $\mathrm{Co}_{3} \mathrm{O}_{4}$ atomic layer slab and (D) bulk $\mathrm{Co}_{3} \mathrm{O}_{4}$ slab. Figure taken from Ref. [27].

suitable dispersion of $\mathrm{Ni}$ atoms and thus provide a more active reaction site. This work supports the approach to construct high performance catalysts with abundant active sites and advances the catalysts' design for electrochemical $\mathrm{CO}_{2}$ reduction applications. With the assistant of metal-organic frameworks, $\mathrm{Li}$ et al. [36] synthesized single $\mathrm{Ni}$ atoms for electrochemical $\mathrm{CO}_{2}$ reduction. The synthesis is based on ionic exchange between $\mathrm{Zn}$ nodes and adsorbed Ni ions (Fig. 6(a)). Ni and $\mathrm{N}$ were homogeneously dispersed on the whole structure (Fig. 6(b)-(g)). This structure enables abundant low-coordinated sites on the surface and thus provide excellent performance. The composite shows a different mechanism for the reduction process with a Tafel value of $249 \mathrm{mV} \mathrm{dec}^{-1}$. The electrolysis in this system could act as a proton donor and a transporter of $\mathrm{CO}_{2}$, thus promoting the efficiency of the electrochemical $\mathrm{CO}_{2}$ reduction. Li et al. [37] prepared atomically dispersed $\mathrm{Ni}$ on $\mathrm{Ni}$-doped graphene and identified the monovalent $\mathrm{Ni}$ atomic center as the catalytically active site. The obtained single-Ni-atom catalyst exhibits high intrinsic $\mathrm{CO}_{2}$ reduction activity, achieving high current density of $110 \mathrm{~mA} \mathrm{~cm}^{-2}$ at an overpotential of $1 \mathrm{~V}$ (Fig. 7(a)) and turnover frequency of 14,800 $\mathrm{h}^{-1}$ at an overpotential of $0.61 \mathrm{~V}$ (Fig. 7(c)) with 97\% Faradaic efficiency (Fig. 7(b)). The catalyst also showed long-term stability as it maintained a at high current density for $100 \mathrm{~h}$ (Fig. 7(d)).

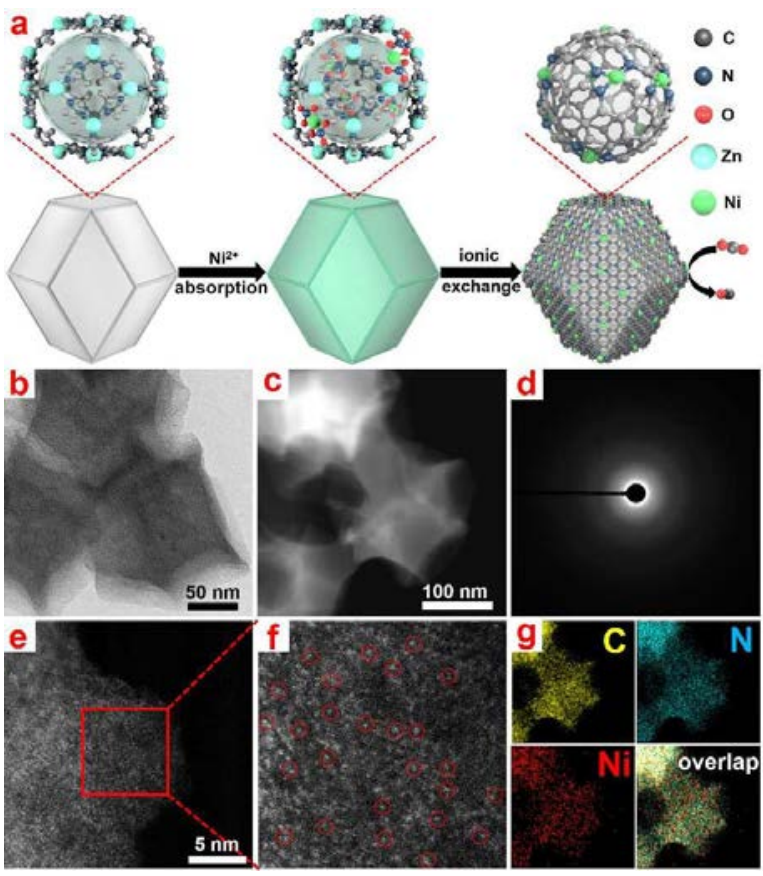

Fig. 6. (a) Scheme of the formation of the single Ni atom on Ni-doped carbon. (b) TEM and (c) HAADF-STEM images. (d) SAED pattern, (e, f) magnified HAADF-STEM images. Red circles: Single Ni atoms. (h) Corresponding EDS map images. Figure taken from Ref. [36]. 

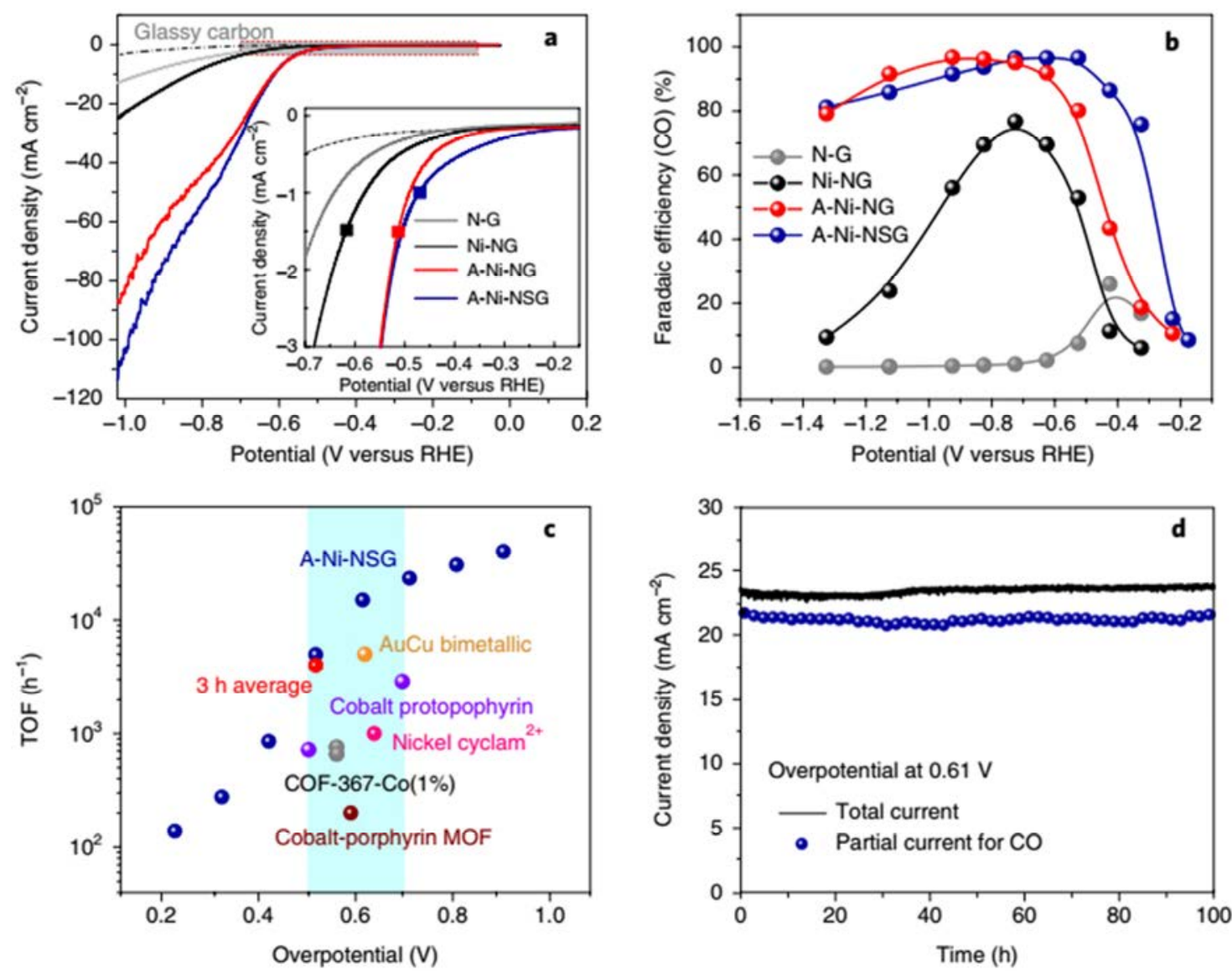

Fig. 7. Electrochemical $\mathrm{CO}_{2}$ reduction performance. (a) Linear sweep voltammetry (LSV) curves. (b) Faradaic efficiency at different applied potentials. (c) Turnover frequency at different applied potentials. (d) Stability tests. Figure taken from Ref. [37].

\section{Conclusions and outlook}

The employment of Mo, Fe, Co, and Ni-based materials as catalysts has numerous possibilities in electrochemical $\mathrm{CO}_{2}$ reduction applications. Herein, we focus on the recent advances of $\mathrm{Mo}, \mathrm{Fe}, \mathrm{Co}$, and $\mathrm{Ni}$-based materials in the $\mathrm{CO}_{2}$ reduction process. Through different approaches, highly efficient and selective catalysts were obtained. However, despite these advances, there are still some challenges in this field:

(1) High energy barriers for the formation of the key intermediate $\mathrm{CO}_{2}{ }^{--}$always causes a large overpotential. In addition, the insufficient mass transfer ability of $\mathrm{CO}_{2}$ to the catalyst surface also limits the efficiency of the reduction process. Catalysts that simultaneously exhibit small overpotential (e.g. $<0.2 \mathrm{~V}$ ) and high current densities (e.g. $>1 \mathrm{~A} \mathrm{~cm}^{-2}$ ) are still required to be developed for commercial applications .

(2) The electrochemical $\mathrm{CO}_{2}$ reduction involves multiple electron/proton coupling processes and different reaction pathways could exist on a fixed overpotential. It remains a challenge to efficiently reduce $\mathrm{CO}_{2}$ to desirable products.

(3) The electrochemical $\mathrm{CO}_{2}$ reduction process always leads to the formation of both gaseous and liquid products. The rapid desorption of products would destroy the microstructure and block electrolyte diffusion. In addition, the active sites of catalysts can also be blocked or poisoned by reaction intermediates, by-products, and impurities from the electrolyte. The stability of catalysts reported so far is yet to reach $1000 \mathrm{~h}$.

(4) The electrochemical $\mathrm{CO}_{2}$ reduction process is a complex reaction. The precise role of the Mo, $\mathrm{Fe}, \mathrm{Co}$, and Ni-based materials, as well as the electrolysis, in improving the activity is still not clear, and is sometimes conflicting. The development of Mo, $\mathrm{Fe}, \mathrm{Co}$, and Ni-based materials as electrochemical $\mathrm{CO}_{2}$ reduction catalysts is still in its infancy, both with respect to the synthesis of advanced catalysts and understanding its detailed mechanisms. Research and development of this field of study is therefore urgently needed.

(1) Exploring new catalysts for electrochemical $\mathrm{CO}_{2}$ reduction will be one of core research goals in the next few years. With regard to the development of catalysts, the potential candidates, including transition metal nitrides, phosphides, carbides, and borides can be explored for use in $\mathrm{CO}_{2}$ reduction.

(2) The surface morphology structure plays the central role in determining the activity and selectivity of the catalyst during electrochemical $\mathrm{CO}_{2}$ reduction. If placed in the correct morphology and electronic structure, a nearly non-catalytic compound may become very active catalyst. The electrochemical $\mathrm{CO}_{2}$ reduction involves the interaction between solids, liquids, and gases. The local concentration of $\mathrm{CO}_{2}$ surrounding typical catalysts and the contact between different phases, together 
with the surface area of electrocatalysts, limit the efficiency of electron/mass transfer to the active sites. The innovative design and synthesis of different unique nanostructures would significantly increase the catalytic active sites, shorten the paths for charge/mass transport, promote the interaction with $\mathrm{CO}_{2}$, and facilitate desorption of products, thus improving electrochemical reaction performance.

(3) In principle, the intrinsic activity and selectivity of catalysts are determined wholly by its surface electronic structure. The surface electronic structure strongly influences the multiple-step electron and proton coupling processes, thus determining the intrinsic activity and selectivity towards electrochemical $\mathrm{CO}_{2}$ reduction. For Mo, $\mathrm{Fe}, \mathrm{Co}$, and Ni-based materials, the electrocatalytic properties are related to its $d$ state electrons. For example, the $p$-state (e.g. N, S) doping would perturb or potentially hybridize with the continuous $d$-states. As the result, the scaling relations between the carbonaceous adsorbates would not be applicable and the overpotential would therefore decrease. As such, the optimization of $d$-state structures related to various intermediate adsorption reactions [12] hold great promise for the improvement of intrinsic catalytic activity and selectivity.

(4) The fundamental understanding of electrochemical properties, electron transfer kinetics, and multiple-electron coupled mechanisms are limited. Currently, there are still barriers for precisely detailing the geometric parameters of catalysts in a large-scale setting. The measured performance only reflects the average properties of catalysts. This may lead to the conclusion of a statistically false-positive result if the geometric parameter is random. To better understand the mechanisms of electrochemical $\mathrm{CO}_{2}$ reduction at an atomic level, the utilization of more precise models is highly desirable. In addition, the integration of theoretical simulation and in situ characterization techniques would beneficial for clarifying the catalytic mechanisms.

\section{References}

[1] E. V. Kondratenko, G. Mul, J. Baltrusaitis, G. O. Larrazabal, J. Perez-Ramirez, Energy Environ. Sci., 2013, 6, 3112-3135.
[2] L. Zhang, Z. J. Zhao, J. L. Gong, Angew. Chem. Int. Ed., 2017, 129, 11482-11511.

[3] J. L. Qiao, Y. Y. Liu, F. Hong, J. J. Zhang, Chem. Soc. Rev., 2014, 43, 631-675.

[4] H. Wang, J. Jia, P. F. Song, Q. Wang, D. B. Li, S. X. Min, C. X. Qian, L. Wang, Y. F. Li, C. Ma, T. Wu, J. Y. Yuan, M. Antonietti, G. A. Ozin, Angew. Chem. Int. Ed., 2017, 56, 7847-7852.

[5] S. Zhang, P. Kang, S. Ubnoske, M. K. Brennaman, N. Song, R. L. House, J. T. Glass, T. J. Meyer, J. Am. Chem. Soc., 2014, 136, 7845-7848.

[6] J. J. Wu, R. M. Yadav, M. J. Liu, P. P. Sharma, C. S. Tiwary, L. L. Ma, X. L. Zou, X. D. Zhou, B. I. Yakobson, J. Lou, P. M. Ajayan, ACS Nano, 2015, 9, 5364-5371.

[7] B. Kumar, M. Asadi, D. Pisasale, S. Sinha-Ray, B. A. Rosen, R. Haasch, J. Abiade, A. L. Yarin, A. Salehi-Khojin, Nat. Commun., 2013, 4, 2819.

[8] B. Hammer, J. K. Norskov, Nature, 1995, 376, 238-240.

[9] K. Chan, C. Tsai, H. A. Hansen, J. K. Nørskov, ChemCatChem, 2014, 6, 1899-1905.

[10] X. Hong, K. Chan, C. Tsai, J. K. Nørskov, ACS Catal., 2016, 6, 4428-4437.

[11] M. Asadi, B. Kumar, A. Behranginia, B. A. Rosen, A. Baskin, N. Repnin, D. Pisasale, P. Phillips, W. Zhu, R. Haasch, R. F. Klie, P. Král, J. Abiade, A. Salehi-Khojin, Nat. Commun., 2014, 5, 4470.

[12] M. Asadi, K. Kim, C. Liu, A. V. Addepalli, P. Abbasi, P. Yasaei, P. Phillips, A. Behranginia, J. M. Cerrato, R. Haasch, P. Zapol, B. Kumar, R. F. Klie, J. Abiade, L. A. Curtiss, A. Salehi-Khojin, Science, 2016, 353, 467-470.

[13] X. F. Sun, L. Lu, Q. G. Zhu, C. Y. Wu, D. X. Yang, C. J. Chen, B. X. Han, Angew. Chem. Int. Ed., 2018, 57, 2427-2431.

[14] P. Abbasi, M. Asadi, C. Liu, S. Sharifi-Asl, B. Sayahpour, A. Behranginia, P. Zapol, R. Shahbazian-Yassar, L. A. Curtiss, A. Salehi-Khojin, ACS Nano, 2017, 11, 453-460.

[15] X. F. Sun, Q. G. Zhu, X. C. Kang, H. Z. Liu, Q. L. Qian, Z. F. Zhang, B. X. Han, Angew. Chem. Int. Ed., 2016, 55, 6771-6775.

[16] G. D. Shi, L. Yu, X. Ba, X. S. Zhang, J. Q. Zhou, Y. Yu, Dalton Trans., 2017, 46, 10569-10577.

[17] J. B. Varley, H. A. Hansen, N. L. Ammitzbøll, L. C. Grabow, A. A. Peterson, J. Rossmeisl, J. K. Nørskov, ACS Catal., 2013, 3, 2640-2643.

[18] C. Costentin, S. Drouet, M. Robert, J. M. Savéant, Science, 2012, 338, 90-94.

[19] C. Costentin, M. Robert, J. M. Savéant, A. Tatin, Proc. Natl. Acad. Sci.

\section{Graphical Abstract}

Chin. J. Catal., 2018, 39: 1157-1166 doi: 10.1016/S1872-2067(18)63073-6

Transition metal (Mo, Fe, Co, and $\mathrm{Ni}$ )-based catalysts for electrochemical $\mathrm{CO}_{2}$ reduction

Jinhui Hao, Weidong Shi *

Jiangsu University

Transition metal (Mo, Fe, Co and Ni)-based catalysts with well-defined $d$-state structure provided a fast electron transfer process for intermediate adsorption and thus exhibited high intrinsic activity for the electrochemical $\mathrm{CO}_{2}$ reduction process.

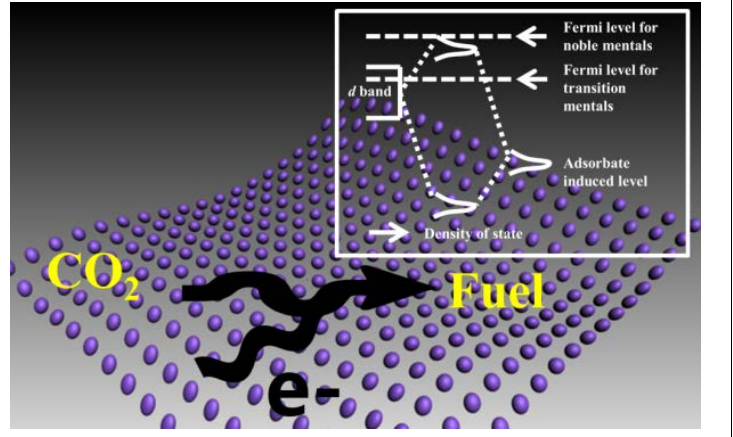


USA, 2015, 112, 6882-6886.

[20] A. Maurin, M. Robert, J. Am. Chem. Soc., 2016, 138, 2492-2495.

[21] J. Choi, T. M. Benedetti, R. Jalili, A. Walker, G. G. Wallace, D. L. Officer, Chem. Eur. J., 2016, 22, 14158-14161.

[22] E. A. Mohamed, Z. N. Zahran, Y. Naruta, Chem. Mater., 2017, 29, 7140-7150.

[23] N. Y. Dzade, A. Roldan, N. H. de Leeuw, J. Chem. Phys., 2015, 143, 094703.

[24] S. Wannakao, N. Artrith, J. Limtrakul, A. M. Kolpak, ChemSusChem, 2015, 8, 2745-2751.

[25] F. P. Pan, W. Deng, C. Justiniano, Y. Li, Appl. Catal. B, 2018, 226, 463-472.

[26] S. Gao, Y. Lin, X. C. Jiao, Y. F. Sun, Q. Q. Luo, W. H. Zhang, D. Q. Li, J. L. Yang, Y. Xie, Nature, 2016, 529, 68-71.

[27] S. Gao, X. C. Jiao, Z. T. Sun, W. H. Zhang, Y. F. Sun, C. M. Wang, Q. T. Hu, X. L. Zu, F. Yang, S. Y. Yang, L. Liang, J. Wu, Y. Xie, Angew. Chem. Int. Ed., 2016, 55, 698-702.

[28] S. Gao, Z. T. Sun, W. Liu, X. C. Jiao, X. L. Zu, Q. T. Hu, Y. F. Sun, T. Yao, W. H. Zhang, S. Q. Wei, Y. Xie, Nat. Commun., 2017, 8, 14503.

[29] Y. B. Yan, K. X. Li, X. P. Chen, Y. H. Yang, J. M. Lee, Small, 2017, 13, 1701724.
[30] G. Z. Zhu, Y. W. Li, H. Y. Zhu, H. B. Su, S. H. Chan, Q. Sun, ACS Catal., 2016, 6, 6294-6301.

[31] C. L. Yao, J. C. Li, W. Gao, Q. Jiang, Phys. Chem. Chem. Phys., 2017, 19, 15067-15072.

[32] X. Zhang, X. Zhang, L. W. Li, Y. Y. Li, H. M. Xu, X. X. Li, X. L. Yu, Z. S. Zhang, Y. Y. Liang, Z. S. Wu, H. L. Wang, Nat. Commun., 2017, 8, 14675.

[33] X. M. Hu, M. H. Rønne, S. U. Pedersen, T. Skrydstrup, K. Daasbjerg, Angew. Chem. Int. Ed., 2017, 56, 6468-6472.

[34] P. P. Su, K. Iwase, S. Nakanishi, K. Hashimoto, K. Kamiya, Small, 2016, 12, 6083-6089.

[35] X. G. Li, W. T. Bi, M. L. Chen, Y. X. Sun, H. X. Ju, W. S. Yan, J. F. Zhu, X. J. Wu, W. S. Chu, C. Z. Wu, Y. Xie, J. Am. Chem. Soc., 2017, 139, 14889-14892.

[36] C. M. Zhao, X. Y. Dai, T. Yao, W. X. Chen, X. Q. Wang, J. Wang, J. Yang, S. Q. Wei, Y. E. Wu, Y. D. Li, J. Am. Chem. Soc., 2017, 139, 8078-8081.

[37] H. B. Yang, S. F. Hung, S. Liu, K. D. Yuan, S. Miao, L. P. Zhang, X. Huang, H. Y. Wang, W. Z. Cai, R. Chen, J. J. Gao, X. F. Yang, W. Chen, Y. Q. Huang, H. M. Chen, C. M. Li, T. Zhang, B. Liu, Nat. Energy, 2018, 3, 140-147.

\title{
过渡金属(Mo, Fe, Co和Ni)基催化剂在电催化还原二氧化碳还原中应用
}

\author{
郝金辉，施伟东* \\ 江苏大学化学化工学院, 江苏镇江 212013
}

\begin{abstract}
摘要: 近年来, 全球二氧化碳排放量逐年增加, 对人们赖以生存的生态环境已造成严重威胁, 因此将二氧化碳转化成高附 加值的化学品和燃料受到前所未有的广泛关注. 与目前已开发的转化技术 (如热催化和光催化等) 相比, 电催化二氧化碳 转化技术具有稳定的效率、可控的选择性、简单的反应单元和巨大的工业应用潜力, 是一种更为理想的转化技术之一. 从 反应动力学来看, 目前的催化剂仍难以克服反应过程中高的能量屏障以及迟缓的反应速度. 另一方面, 电催化二氧化碳转 化包含多个质子和电子的耦合过程, 反应过程包含多种路径, 反应产物往往是混合物. 在此背景下, 如何发展高催化效率 和高选择性电催化剂成为目前研究的焦点. 在众多的电催化剂中, 贵金属及其合金展现出较高的电催化二氧化碳还原活 性, 但储量小的缺点限制了其大规模的工业应用. 铜基材料可以把二氧化碳转化为附加值更高的产品. 然而, 铜基材料仍 难以克服选择性差、失活严重和效率低等缺点. 作为一种更廉价的材料, 碳基催化剂具有价廉、比表面积大、导电性好、 化学性质稳定以及优异的机械性能等优点在电催化二氧化碳还原中得到了广泛的研究. 然而, 单纯的碳催化剂对于二氧 化碳分子活化以及吸附反应中间体能力较低, 导致了碳基材料催化电催化二氧化碳还原活性以及选择性较低. 因此, 开发 出可实际应用的高效率和高选择性非贵金属电极材料是当前该技术研究中亟待解决的关键科学问题.

过渡金属基化合物在能源转化中展现出巨大的应用潜力. 过渡金属价电子在 $d$ 轨道, 而 $d$ 轨道邻近费米能级, $d$ 轨道电 子填充的变化使得 $d$ 轨道中心与费米能级相对位置发生变化, 进而展现出多种催化活性. 电催化二氧化碳还原是一个多电 子和质子耦合过程, 催化剂的本征活性由其表面电子结构决定. 在此背景下, 过渡金属基化合物价层电子轨道的多变性使 其成为提高电催化二氧化碳还原效率和选择性的理想催化剂. 对于电催化二氧化碳还原, 不同中间体的标度关系是制约 反应总效率的关键因素. Nørskov等研究发现, $\mathrm{MoS}_{2}, \mathrm{MoSe}_{2}$ 和 $\mathrm{Ni}$ 掺杂 $\mathrm{MoS}_{2}$ 催化剂上存在不同种类的活性位点. 不同的活 性位点可以分别吸附反应中间体并使中间体的吸附过程相对独立，从而有效打断中间体的标度关系. 2014年, Salehi-Khojin等成功把 $\mathrm{MoS}_{2}$ 应用在高效电催化二氧化碳还原中. 边缘Mo原子 $d$ 带电子靠近费米能级的特性使其具有更高 的电催化活性. 其它研究工作者通过引入掺杂物质, 进一步提高了 $\mathrm{MoS}_{2}$ 的电催化二氧化碳还原性能. Fe位点在理论上虽 然具有很高的电催化二氧化碳转化活性, 然而目前铁基催化剂的研究相对较少. Co基材料也可用于电催化二氧化碳转化. 2016年, Xie等首次制备无机Co 基材料用于电催化二氧化碳还原. 部分氧化的钴可以促进速控步骤反应进程, 进而降低整 体反应的过电势. 基于此, 制备了超薄的 $\mathrm{Co}_{3} \mathrm{O}_{4}$ 片层, 发现价电子轨道中心更靠近费米能级时, 电极材料展现出更高的催化 活性. 进一步研究发现氧空穴的存在也可以减小速控步骤的能量屏障. 此外, $\mathrm{Ni}$ 基材料也被证明具有高的催化二氧化碳转 化活性. 目前这些研究工作对如何构建高性能电极材料在理论上给出了指导方向, 并且联系实验证明了方法的可行性. 受 到这些工作的启发, 未来可将有巨大潜力的过渡金属基化合物化合物, 例如过渡金属氮化物、过渡金属磷化物、过渡金属
\end{abstract}


碳化物和过渡金属硼化物等, 作为电催化剂研究其二氧化碳还原催化性能. 另外, 就目前的研究来看, 将二氧化碳有效地 还原到特定的产物仍存在巨大的挑战. 如何优化过渡金属(Mo, Fe, Co和 $\mathrm{Ni}$ )基催化剂价层 $d$ 轨道结构, 促进反应中间体吸附 过程, 将是解决催化活性和选择性这一科学问题的关键.

关键词: 过渡金属; 能源转换; 电催化; 二氧化碳

收稿日期: 2018-02-22. 接受日期: 2018-04-07. 出版日期: 2018-07-05.

*通讯联系人. 电子信箱: swd1978@ujs.edu.cn

基金来源：国家自然科学基金(21477050，21522603，21706101); 霍英东教育基金(141068); 江苏省六大人才高峰计划(XCL-025);

中德合作项目(GZ1091); 中国博士后基金会(2017M611731).

本文的电子版全文由Elsevier出版社在ScienceDirect上出版(http://www.sciencedirect.com/science/journal/18722067). 